\title{
BIOMETRICAL CHARACTERISTICS OF $\mathbf{R}_{2}$ GENERATION OF ANTHER-DERIVED PEPPER (Capsicum spp.) PLANTS
}

\author{
Anna Kisiała, Dorota Olszewska, Aleksandra Niklas-Nowak, Paweł Nowaczyk \\ Department of Genetics and Plant Biotechnology, University of Technology and Life Sciences, \\ 7 Kaliskiego Ave., 85-789 Bydgoszcz, Poland \\ e-mail: a.kisiala@utp.edu.pl
}

Received: 21.10 .2010

\section{Abstract}

Eight anther-derived DH lines of pepper hybrids: two red-fruited (AP14, AP15) and two yellow lines (AP25 and $\mathrm{AP} 32)$ of $C$. annuum $(\mathrm{ATZ} 1 \times \mathrm{PO}) \mathrm{F}_{2}$, two lines of $(C$. frutescens $\times$ C. annuum $) \mathrm{F}_{1}(\mathrm{FA} 1, \mathrm{FA} 2)$, and two of $(C$. frutescens $\times C$. chinense $\mathrm{F}_{1}(\mathrm{FCH} 2, \mathrm{FCH} 3)$, were studied regarding important morphological plant and fruit characters. C. annuum breeding line 'ATZ1' was used as a standard. The following traits were evaluated: total fruit yield, fruit weight, weight of placenta with seeds, technological matter, pericarp thickness, extract content, dry matter content, weight and number of seeds per fruit. The level of homogeneity within the DH lines was analysed with a one-way analysis of variance, additionally the values of coefficient of variation $(\mathrm{CV})$ were determined for the tested plant characters. The highest phenotypic uniformity was noted for the red-fruited lines obtained from anthers of (ATZ1 $\times \mathrm{PO}) \mathrm{F}_{2}$ and for the $\mathrm{DH}$ lines of $(C$. frutescens $\times$ C. annuum) $\mathrm{F}_{1}$, while the least uniform were $\mathrm{FCH} 2$ and $\mathrm{FCH} 3$ lines of (C. frutescens $\times C$. chinense) $\mathrm{F}_{1}$. The DH lines AP14 and AP15, as well as FA1 and FA2 were phenotype homogeneous in respect of weight of fruit, technological matter, pericarp thickness and extract content. For these parameters, also the values of $\mathrm{CV}$ were the lowest. Statistically significant interline polymorphism between the androgenic lines of the same origin was detected among the lines of $C$. annuum $(\mathrm{ATZ} 1 \times \mathrm{PO}) \mathrm{F}_{2}$.

Key words: Capsicum, anther culture, androgenic regenerants, morphological characteristics

\section{INTRODUCTION}

In pepper in vitro anther cultures, besides haploid plants, diploid and mixoploid forms can also develop. As for pepper, diploids among androgenic regenerants are most often the result of spontaneous duplication of the number of chromosomes in haploid cells at the initial stages of embryo development ( $\mathrm{V}$ a gera, 1990; Gyulai et al. 2000). Spontaneously diploidized DH lines produced this way present a fully homozygotic set of genes and as such they constitute very precious breeding material which does not segregate in successive breeding years. The morphological characteristics of selected plant and fruit characters, carried out in successive generations of anther culture-derived diploid regenerants, can be very helpful in testing of genetic homogeneity within a single DH line and the genetic polymorphism that occurs between different androgenic pepper lines. High phenotypic homogeneity of androgenic population reflects its considerable homozygocity (V a g e r a , 1990; S u p e n a et al. 2006). Additionally, the morphological evaluation of DH lines, besides allowing the confirmation of genetic homogeneity of a single line, makes it also possible to present the diversity across different lines obtained in anther cultures ( $\mathrm{Ne} \mathrm{r} v$ o et al. 1995). This variation between $\mathrm{DH}$ lines reflects the genetic diversity of microspores, which results from random gene segregation in meiosis, and is one of the most important conditions of in vitro androgenesis practical applicability to plant breeding (G é m e s n é et al. 2001).

The usefulness of induced androgenesis in pepper breeding depends on a broad diversity of anther-derived DH lines, as it facilitates the selection of individuals with interesting agronomical traits. This is the reason why the most precious anther donors are heterozygous. Heterogeneity of these plants may considerably shorten the time of obtaining lines with a new valuable gene combination of both parental forms of the hybrid (Mi t y k ó et al. 1995). 
The main aim of this work was to apply the biometrical analysis of eight $\mathrm{R}_{2}$ androgenic generations of three pepper hybrids: $C$. annuиm $(\mathrm{ATZ1} \times \mathrm{PO}) \mathrm{F}_{2}$, $(C$. frutescens $\times C$. annuum $) \mathrm{F}_{1}$, and $(C$. frutescens $\times$ C. chinense) $\mathrm{F}_{1}$, for the estimation of homogeneity within the tested DH lines, as well as for the presentation of the morphological diversity between the lines of the same origin.

\section{MATERIALS AND METHODS}

Eight DH lines of Capsicum obtained as a result of self-pollination of anther-derived diploid regenerants were investigated in the experiment: four lines of C. anпиит L. $(\mathrm{ATZ} 1 \times \mathrm{PO}) \mathrm{F}_{2}$ hybrid - AP14, AP15 (red-fruited), and AP25 and AP32 (yellow-fruited), FA1 and FA2 lines of $(C$. frutescens $\mathrm{L} . \times C$. annuum $\mathrm{L}.) \mathrm{F}_{1}$, and $\mathrm{FCH} 2$ and $\mathrm{FCH} 3$ lines of $(C$. frutescens $\mathrm{L}$. $\times C$. chinense Jacq.) $\mathrm{F}_{1}$. Additionally, the ATZ1 breeding line of $C$. аппиит - the first Polish breeding line, well adapted to local soil and climate conditions - was used as a standard cultivar for the biometrical tests. Plants were grown in polytunnels following the standard pepper growing methodology. Ploidy level of $\mathrm{R}_{1}$ androgenic regenerants was analysed cytometrically (Galbraith et al. 1985).

From each of the tested populations, 15 plants were selected and total fruit yield per plant was determined. Besides, for the purpose of detailed analysis, two fruits were sampled per plant. The biometrical studies evaluated the following fruit characters: fruit weight, weight of placenta with seeds, technological matter (pericarp without placenta), pericarp thickness, extract content (optically active compounds), dry matter content, weight of seeds and number of seeds per fruit. The morphological characters of plants and fruits were estimated according to the principles provided for in 'Descriptors for Capsicum (Capsicum ssp.)' (1995).

The phenotypic uniformity of the tested androgenic lines was determined with analysis of variance (ANOVA/MANOVA). The phenotypic diversity across the lines of the same origin (lines derived from anthers of a particular hybrid) was evaluated on the basis of Scheffe's multiple range test results. For all the characters tested, there were also defined the values of standard deviation (SD) and the coefficient of variation $(\mathrm{CV})$.

\section{RESULTS}

The $\mathrm{R}_{2}$ progeny of eight diploid plants obtained in anther culture of $C$. annuиm $(\mathrm{ATZ1} \times \mathrm{PO}) \mathrm{F}_{2}$ hybrid,
(C. frutescens $\times$ C. annuum) $\mathrm{F}_{1}$ and $(C$. frutescens $\times$ C. chinense) $\mathrm{F}_{1}$ was investigated in this study, in spite of their morphological characteristics. The results of the analysis are given in Table 1.

The analysis of variance performed on the biometrical characteristics of the $R_{2}$ generation of androgenic diploid plants confirmed the highest phenotypic homogeneity of four of the tested pepper DH lines in the case of yield and all the fruit parameters in question. Two of these genotypes - AP14 and AP15, originated from anthers of the hybrid composed of $C$. annuum cultivated lines - ATZ1 and PO, whereas the other two - FA1 and FA2, were obtained in anther cultures of an interspecific hybrid between $C$. frutescens and $C$. annuum, used as a pollinator. The DH lines AP14 and AP15, as well as FA1 and FA2 were homogenous in respect of weight of fruit, technological matter, pericarp thickness, and extract content. The statistical analysis of the other four tested lines, especially these derived from diploid $\mathrm{R}_{1}$ regenerants of $(C$. frutescens $\times C$. chinense $) \mathrm{F}_{1}$, did not show such a high level of morphological uniformity (Table 1).

The phenotype homogeneity of DH lines obtained in anther cultures of $C$. anпиит (ATZ1 $\times \mathrm{PO}) \mathrm{F}_{2}$ and $(C$. frutescens $\times C$. annuum $) \mathrm{F}_{1}$ hybrids was confirmed also by the low values of the coefficient of variation $(\mathrm{CV})$. They were very similar to the $\mathrm{CV}$ parameters obtained for the breeding line ATZ1, particularly in case of the red-fruited lines AP14 and AP15. On the other hand, the highest CV values, very often exceeding 30\%, were typical for the genotypes FCH2 and $\mathrm{FCH} 3$, originated from the hybrid of two wild species of Capsicum. Rather high CV values were recorded also for fruit yield per plant in case of the DH lines derived from the hybrids composed of at least one wild species. In general, out of nine parameters analysed, for most of the tested androgenic populations the lowest values of $\mathrm{CV}$ were noted for pericarp thickness and extract content $(<20 \%)$, while the highest ones for the characters concerning fruit fertility (>30\%) (Table 1).

Besides, to provide a broader picture of variation that occurs between androgenic plants of the same origin, the degree of variation across the anther-derived DH lines of each of the three studied pepper hybrids was statistically evaluated. The results of Scheffe's significance test revealed the highest phenotypic diversity in case of androgenic lines of the hybrid (ATZ1 $\times$ PO) $\mathrm{F}_{2}$, for which only the total yield level and the number of seeds per fruit were not significantly different between the compared DH lines (Table 1). 
Table 1

Biometrical characteristics of pepper DH lines

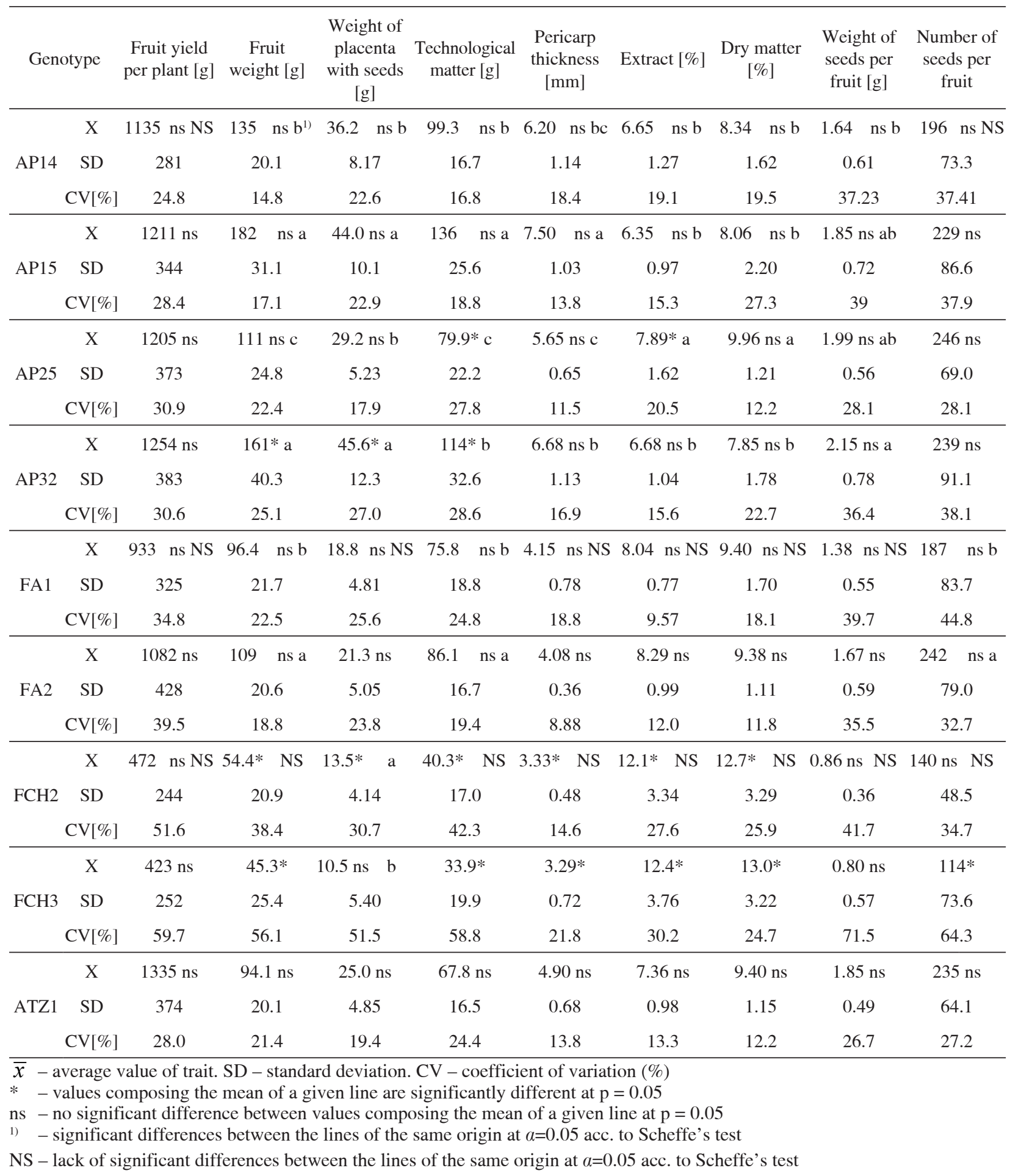

\section{DISCUSSION}

Practical application of anther cultures to pepper breeding is possible only if the process is effective and results in pure lines of doubled haploids. Such lines can develop, e.g., thanks to spontaneous diploidization of haploid embryos (Gyulai et al. 2000). V a ge r a (1990) claims that the formation of spontaneously doubled haploids in anther cultures is observed much more often in pepper than in other Solanaceae species. The development of diploid regenerants of microspore origin in pepper anther cultures is usually explained 
by the lack of tendency to indirect embryogenesis via callus phase, neither to the formation of embryos from somatic anther tissues. However, before anther-derived diploid plants are included into further breeding programs, it is necessary to confirm their gametophyte origin and thus their full homozygocity.

Nervo et al. (1995) and Supena et al. (2006) propose that the gametophytic origin of androgenic pepper regenerants can be confirmed based on the high morphological homogeneity of $\mathrm{R}_{2}$ generation, obtained as a result of self-pollination of diploid plants derived from anther cultures. Phenotypic homogeneity of an androgenic population can point to the high level of its homozygocity. Besides, due to a necessity of providing a biometrical description of the most important plant and fruit parameters, this method additionally allows for a simultaneous selection of the lines which present the characters of interest to breeders and for allocating them for further breeding work. And, what is important, it does not demand using very sophisticated and expensive research tools.

The results of the analysis of variation show that the highest homogeneity of plant and fruit biometrics was characteristic for two pepper lines - AP14 and AP15, derived from anther cultures of the hybrid composed of cultivated $C$. аппиит lines, and in the androgenic populations FA1 and FA2, obtained from the hybrid $\left(C\right.$. frutescens $\times C$. annuum) $\mathrm{F}_{1}$. However, it was not found to such a high degree in case of the other four androgenic lines evaluated in this work, including the yellow-fruited AP25 and AP32. The presented results suggest that the morphological characteristic of Capsicum androgenic lines is not a method sufficient enough for verification of their genotype uniformity, because the yellow colour of the DH lines, derived from anthers of the red-fruited $C$. annuиm hybrid is the marker character proving their microspore origin. Additionally, the lack of phenotypic homogeneity may result from the environmental variation, which can have a modifying effect on the morphological characters of the genotypes cultivated in Poland, especially those derived from the hybrid of the wild pepper species $C$. frutescens and $C$. chinense. For example, Kozdój and Oleszczuk (2006), who analysed heterogeneity of some economically important traits of DH lines of barley, present comparable results.

It is also noteworthy that interlinear phenotypic polymorphism between the tested DH lines was observed in the experiment, especially in case of the lines produced in anther cultures of the hybrid $($ ATZ1 $\times$ PO) $\mathrm{F}_{2}$, in respect of such economically important traits as fruit total weight and technological matter, or pericarp thickness. That phenotypic diversity reflects the gene- tic variability of microspores they originated from and is a very essential character of androgenic populations, since it greatly facilitates the selection of plants valuable for breeders. It can help in considerable broadening of variation that occurs in pepper cultivars grown so far. Moreover, the performed biometrical analysis of six of the tested DH lines showed that yielding and the quality value of the lines, especially the ones obtained in anther cultures of the C. annuиm hybrid, are comparable with ATZ1 used as a reference line in this experiment as well as with other breeding lines and pepper cultivars from our germplasm collection (K i s i a ł a , 2008).

The results obtained in the present research show that anther culture-derived DH lines of Capsicum may constitute a precious source of new genetic variation and may be used as a source material for pepper breeding. Therefore, it seems to be justifiable to prove the genetic uniformity of DH lines, especially these originated from wild pepper forms also with more specific techniques. Apart from morphological characters of the progeny of anther culture-derived diploids, verification of their microspore origin is also possible by DNA molecular analysis of androgenic regenerants ( $\mathrm{N}$ e r v o et al. 1995; G y u l a i et al. 2000) or by isosyme markers (Dolcet-Sanjuan et al. 1997).

\section{CONCLUSIONS}

Biometrical analysis of pepper doubled haploid lines constitutes a very important part of breeding work, as it allows for the assessment of agronomical value of the lines and facilitates the selection of the most interesting populations for further research. Additionally, examination of morphological characters of plants and fruits helps to reveal desirable interline polymorphism often occurring between androgenic lines of the same origin.

\section{REFERENCES}

Dolcet-Sanjuan R., Claveria E., Huerta A., 1997. Androgenesis in Capsicum annuиm L.: effect of carbohydrate and carbon dioxide enrichment. J. Amer. Soc. Hortic. Sci. 122: 468-475.

Galbraith D.W., Harkins K.R., Maddox J.M., Ayres N.M., Sharma D.P., Firoozabady E., 1983. Rapid flow cytometry analysis of the cell cycle in intact plant tissues. Science, 220: 1049-1051.

Gémesné J.A., Petus M., Gyulai G., Cséplö M., 2001. Genetic variability of anther donor versus spontaneous doubled haploid descendents and colchicine induced doubled haploid sweet pepper (Capsicum annuum L.) lines. Acta Hort. 560: 149-152. 
Gyulai G., Gémesné J.A., Sági Z.S., Venczel G., Pintér P., Kristóf Z., Törjék O., Heszky I., Bottka S., Kiss J., Zatykó L., 2000. Doubled haploid development and PCR-analysis of $\mathrm{F}_{1}$ hybrid derived $\mathrm{DH}-\mathrm{R}_{2}$ paprika (Capsicum annuum L.) lines. J. Plant Physiol. 156: 168-174.

IPGRI. 1995. Descriptors for Capsicum (Capsicum spp.). International Plant Genetic Resources Institute, Rome, Italy.

$\mathrm{K}$ is i ała A., 2008. The effect of genotype on in vitro androgenesis of pepper (Capsicum annuum L.) PhD Thesis. University of Technology and Agriculture, Bydgoszcz.

Kozdój J., Oleszczuk S., 2006. Analiza zmienności cech plonotwórczych kłosa i rośliny linii podwojonych haploidów jęczmienia jarego (Hordeum vulgare L.). I Analysis of variation in yield-enhancing traits of the ear and plant in a doubled haploid line of spring barley (Hordeum vulgare L.). [In:] Haploidy i linie podwojonych haploidów w genetyce i hodowli roślin. T. Adamski, M. Surma (eds), IGR PAN, Poznań, 109-177. (in Polish)

Mitykó J., Andrásfalvy A., Csilléry G., Fári M., 1995. Anther-culture response in different genotypes and $\mathrm{F}_{1}$ hybrids of pepper (Capsicum annuum L.). Plant Breed. 114: 78-80.

Nervo G., Ferrari V., Caporali E., 1995. Evaluation of anther culture derived plants of pepper. Proceedings of IX ${ }^{\text {th }}$ EUCARPIA Meeting on Genetics and Breeding of Capsicum \& Eggplant, 1995 - Budapest, Hungary: 72-75.

Supena E.D.J., Suharsono S., Jacobsen J., Custers J.B.M., 2006. Successful development of a shed-microspore culture protocol for doubled haploid production in Indonesian hot pepper (Capsicum аnnuum L.). Plant Cell Rep. 25(1): 1-10.

Vagera, J., 1990. Pepper (Capsicum spp.): In vitro induction of haploids. [In: ] Biotechnology in Agriculture and Forestry. Haploids in Crop Improvement I. Y.P.S. Bajaj (ed.) Springer-Verlag, Berlin, 12: 374-392.

\section{Charakterystyka biometryczna linii otrzymanych w kulturach pylników mieszańców papryki (Capsicum spp.)}

\section{Streszczenie}

W pracy oceniono wybrane cechy plonotwórcze ośmiu linii DH, otrzymanych w kulturach pylników mieszańców papryki (Capsicum spp.): C. annuum $(\mathrm{ATZ1} \times \mathrm{PO}) \mathrm{F}_{2}$ (dwie linie czerwonoowocowe - AP14, AP15 i dwie żółtoowocowe - AP25 i AP32), (C. frutescens $\times C$. annuum) $\mathrm{F}_{1}(\mathrm{FA} 1, \mathrm{FA} 2)$ oraz $(C$. frutescens $\times C$. chinense) $\mathrm{F}_{1}(\mathrm{FCH} 2, \mathrm{FCH} 3)$. Linia hodowlana C. annuum ATZ1 została wykorzystana jako standard do porównań. Oceniano całkowity plon owoców z rośliny, masę owocu, masę łożyska z nasionami, masę technologiczną, grubość ścian perykarpu, zawartość ekstraktu i suchej masy oraz masę i liczbę nasion z owocu. Wyrównanie każdej z linii określono przy pomocy analizy wariancji oraz współczynnika zmienności cech $(\mathrm{CV})$. Najwyższą jednorodność fenotypową roślin stwierdzono w przypadku czerwonoowocowych linii DH, otrzymanych w kulturach pylników mieszańców $(\mathrm{ATZ} 1 \times \mathrm{PO}) \mathrm{F}_{2}$ oraz $(C$. frutescens $\times C$. annuит) $\mathrm{F}_{1}$. Linie AP14, AP15 oraz FA1 i FA2 były wyrównane między innymi pod względem masy całkowitej oraz technologicznej owocu, a także grubości ścian perykarpu i zawartości ekstraktu. Dla tych cech odnotowano również najniższe wartości CV. Najmniej wyrównane fenotypowo okazały się linie FCH2 i FCH3, pochodzące $\mathrm{z}$ kultur pylników międzygatunkowego mieszańca $(C$. frutescens $\times C$. chinense $) \mathrm{F}_{1}$. Istotny statystycznie, międzyliniowy polimorfizm cechował cztery androgeniczne linie wewnątrzgatunkowego mieszańca $C$. annuиm $(\mathrm{ATZ1} \times \mathrm{PO}) \mathrm{F}_{2}$. 